\title{
ФРАЗЕОЛОШКА ЈЕДИНИЦА И ПРИСТУПИ У ЊЕНОМ ИЗУЧАВАњУ ${ }^{* *}$
}

\begin{abstract}
У раду који следи предлажу се најпогоднији теоријско-методолошки приступи у изучавању фразеологизма као јединице језичког система и као средства које у одређеној комуникативној ситуацији и нејезичком контексту има веома специфичну употребу. Рад je, при томе, конципиран тако да истакне најважније аспекте одређених савремених лингвистичких струја које испољавају изразиту применљивост на фразеолошком корпусу, без претензија да понуди нове и до сада неиспитане моделе његовог изучавања. У том смислу биће показано како се понуђене теоријско-методолошке парадигме међусобно допуњују дајући мање-више целовиту слику фразеолошке јединице и њене употребе. Стога овај рад представља једну врсту уопштеног прегледа и има више теоријско, а мање емпиријско усмерење.
\end{abstract} матика.

Кључне речи: фразеологизам, когнитивна лингвистика, лингвокултурологија, праг-

\section{1. Уводне напомене}

1.1. У систему језичких јединица фразеологизам се издваја својим особеним обележјима: сложеном структуром, идиоматичношћу, сликовитошћу, експресивношћу и сл., која му обезбеђују посебно место у њему и регулишу његову употребу. Иако показује извесне сличности са другим јединицама, као што су нпр. лексеме, перифразне конструкције (типа донети одлуку), терминолошки изрази и сл., комбинација одговарајућих особина утиче на његову специфичну природу, због чега се фразеологизму може прићи као посебној јединици лексичког система те се и фразеологија може сматрати релативно самосталном дисциплином у односу на лексикологију (Шипка 2006: 124).

*strbacsn@eunet.rs

** Истраживање је рађено у оквиру пројекта Стандардни српски језик: синтаксичка, семантичка и прагматичка истраживања (бр. 178004), који финансира Министарство просвете, науке и технолошког развоја Републике Србије. 
1.2. У истраживању које следи разматрају се јединице које припадају самом језгру фразеологије - према терминологији В. Телије, то су фразеологизми идиоми са номинационом функцијом у језику, као што је имају лексеме, за разлику од клишеа, шаблонског говора, пословица и изрека (в. Телија 1996: 56-83). Фразеологизми су јединице секундарне номинације јер настају семантичким преобликовањем скупа речи тако да се као крајњи резултат добија израз чији семантички садржај није једнак збиру значења његових саставница. Уз то, ове јединице су експресивно обојене, с обавезним присуством конотативне макрокомпоненте у семантичком садржају. Ипак, између примарног значења нефразеолошке базе и њеног секундарног значења, добијеног у поступку фразеологизације, постоји извесна веза, због чега је већина фразеологизама мотивисана. Праћење те мотивације, њено разматрање и тумачење представља у фразеологији најважнији и за истраживаче најпримамљивији проблем, чије решавање води ка проширивању знања у вези с когнитивним способностима говорника, затим с културним миљеом говорне заједнице у којој се користи, као и у вези са законитостима организовања комуникације. У том смислу фразеолошки корпус једног или више језика представља важно поље истраживања у когнитивној лингвистици, лингвокултурологији и прагматици. Когнитивну лингвистику, а пре свега когнитивну семантику и лингвоконцептологију фразеологизми занимају као средства вербализације менталне сфере човековог постојања. Они су показатељи функционисања људског ума који се испољава у језику. За лингвокултурологију фразеологизми су важни као носиоци културних информација и преносиоци културе. И коначно, како су фразеологизми експресивне језичке јединице, тј. носиоци става, оцене и емоционалног односа говорника према предмету говора, њихова улога у комуникацији посебно је значајна за прагматику. Сваки од ових приступа биће размотрен посебно у даљем излагању. ${ }^{1}$

\section{2. Когнитивнолингвистички приступ}

2.1. Когнитивна лингвистика и у оквиру ње когнитивна семантика усмерене су ка расветљавању проблема на релацији језик-мишљење. Централно место у овој дисциплини заузима концепт као основна јединица мишљења, чији се садржаји оваплоћују у језику тако да се испитивањем семантичког простора језика може описати вербализовани део концептосфере (в. Попова/Стерњин 2007: 18-28). Према основним постулатима когнитивне семантике, језик је показатељ не само мисаоног садржаја него и механизама мишљења. Тумачење семантике језичких јединица омогућава да се продре до најсуптилнијих делова људске свести и да се опишу и успоставе основни принципи концептуализације. Тако језик, заправо, открива начин на који

\footnotetext{
${ }^{1}$ У овом истраживању структуралистички приступ фразеологији не само да се не сматра превазиђеним већ се узима као неизбежна метода описа и тумачења фразеолошке грађе, која прати побројане теоријско-методолошке оквире изучавања.
} 
његови говорници поимају и доживљавају свет око себе. Отуда се као најзаступљенији у савременим лингвистичким истраживањима јавља термин језичка слика света (в. нпр. Апресјан 1995; Попова/Стерњин 2007; Маслова 2007; Бартмињски 2011 итд.).

2.2. Као секундарна именовања фразеологизми настају семантичким преобликовањем примарног садржаја, при чему, добијена јединица чува сликовитост мотивационе структуре. Веза између примарног, нефразеолошког и секундарног, фразеолошког садржаја углавном је заснована на доминантним когнитивним механизмима као што су метонимија и метафора. Тако принципи семантичког преобликовања у основи показују начин функционисања људске свести, тј. начин на који човек доживљава и поима стварност која га окружује.

За когнитивну семантику посебно су важне везе које се успостављају између апстрактних појмова као циљних и конкретних као полазних. Разумевање апстрактних категорија преко конкретних, чулима доступних један је од основних постулата когнитивне лингвистике. На тој законитости почивају оба механизма - и метонимија и метафора.

2.3. Метонимија подразумева релацију између два концептуално блиска појма, тј. између два појма која припадају истој концептуалној структури те се један увек може разумети преко другог. Индуктори метонимијске семантичке фразеологизације могу бити различити типови релација међу појмовима: узрок $\rightarrow$ последица, последица $\rightarrow$ узрок, део тела $\rightarrow$ функција коју обавља итд. Модел узРок $\rightarrow$ ПослЕдицА илуструју примери који указују на то да се интелектуално својство схвата преко узрока који га изазива: јести (најести се) бунике 'бити луд, бити без памети, без моћи расуђивања', ${ }^{2}$ јести (појести, најести се) лудих гљива 'бити луд, полудети, не бити при себи', бити ударен (мокрим) обојком 'бити луцкаст, шашав, сулуд' итд. Обрнути модел - последицА $\rightarrow$ узок представљен је примерима са значењем карактерне особине која се разуме преко њене последице: ни мрава не би ко згазио 'бити посве недужан, невин, безазлен', дрхтати над сваким динаром 'бити шкрт, тврдичити, цицијашити', наћи (налазити, тражити) длаку у јајету 'бити веома ситничав; истаћи, истицати као грешку и најмању ситницу' итд. Претпоставља се да овим фразеолошким изразима претходи структура 'толико је добар/безазлен/шкрт/ситничав да'. Метонимијски образац дЕо тЕлА $\rightarrow$ ФукцијА колу оБАвљА веома је чест и уграђен је у знатан број фразеологизама, а навешћемо као пример само оне који показују да се говор схвата преко органа који га производи: отворити (отварати) уста 'почети, почињати говорити', држати језик за зубима, не отворити (отварати) уста 'ћутати'.

2.4. У когнитивној семантици метафора се схвата као механизам мишљења заснован на принципу разумевања апстрактних појмовних домена помоћу конкретних (Лејкоф/Џонсон 2003). За разлику од метонимије, где је реч о истој концептуалној структури, метафора подразумева постојање

\footnotetext{
${ }^{2}$ Примери фразеологизама и значења навођени су према коришћеним општим и фразеолошким речницима.
} 
двају различитих домена међу којима се веза успоставља према некој одређеној врсти асоцијација. Описивање процеса метафоризације у развоју фразеолошког значења, које подразумева откривање мотивационе структуре и тумачење њене повезаности са циљним садржајем, један је од најважнијих задатака когнитивнолингвистичких истраживања. Управо врсте асоцијација успостављене између полазног и циљног домена јасни су показатељи начина на који функционише људска свест. При томе, индуктори метафоричног фразеолошког значења из домена апстрактног могу бити различите категорије: пре свега људско тело, затим простор и релације у њему, искуство стечено у додиру са животињама, биљкама и многим феноменима из природе, предметни ентитети, религијски садржаји итд. ${ }^{3}$ Телесни домен као полазни заступљен је у примерима који показују да се поједини делови тела поимају као садрживачи емоција (имати зло срие на кога 'срдити се, љутити се на некога') или показатељи карактерних особина (имати велико срие 'бити веома добар човек, имати осећаја за туђе невоље, проблеме', бити широких гру$\partial u$ 'имати разумевања, бити великодушан'). Знање о простору и односима у њему, које настаје као резултат интеракције тела с околином, искоришћено је у концептуализацији старости (бити у иявету младости 'бити веома млад'), стања свести (пасти с неба на земљу 'ослободити се илузија, схватити стварност каква јесте'), говорне активности (скакати с предмета на предмет 'говорити неповезано, збркано', дизати кога, шта у облаке 'претерано хвалити некога, нешто'). И друге активности или појмови из домена конкретног могу мотивисати фразеолошка значења која се тичу емоција, мишљења, говора или карактерних и интелектуалних особина људи.

2.5. Међу побројаним доменима телесно искуство је најважнији мотивациони елеменат у процесу семантичке фразеологизације. Према речима М. Џонсона (Џонсон 1987: 2007), оно је уграђено у сликовне шеме као менталне категорије које регулишу наше мишљење. Фразеолошка грађа је веома важан језички доказ идеје о уму који је омеђен телом и који функционише под утицајем телесног искуства. Присуство структуре садржавања и шеме садрживача у нашој свести недвосмислено потврђују примери којима се описују интелектуална својства, здравствена и емоционална стања и сл.: имати мозга у глави, пуцати од здравља, пенити се од беса итд. Затим, шема силе важна је у процесу метафоризације осећања туге, тескобе и потиштености: имати камен на души (сриу), стеже се коме око срия, као и вербалног чина увреде: ујести кога за срие, шибати по чијој глави, дати коме по носу итд. Говорна делатност се разуме још и преко шеме путање: гурати коме, шта под нос, говорити коме, шта у брк и сл.

\footnotetext{
${ }^{3}$ За енглески језик 3. Кевечеш издваја следеће изворне домене: људско тело, здравље и болест, животиње, биљке, грађевине, игре, спорт, новац, светлост, тама итд. (Кевечеш 2010: 18-27).
} 


\section{3. Лингвокултуролошки приступ}

3.1. Когнитивнолингвистичка истраживања фразеологије могу дати добре резултате и указати на постојање универзалних образаца који регулишу људско мишљење. Међутим, у поступку фразеологизације, осим описаних општих когнитивних механизама, важну улогу има и културни филтер, кроз који пролази фразеолошка јединица, чије је значење у многим случајевима веома тешко објаснити ако се он запостави (в. Добровољски/Пирјанен 2005). Присуству културних информација у језику посебну пажњу посвећује лингвокултурологија, млада интердисциплинарна струја у лингвистици, која је почела да се развија деведесетих година двадесетог века у оквиру антропоцентричне парадигме. При томе, антропоцентризам у лингвистици подразумева оријентисаност према човеку као субјекту говора и према његовим механизмима разумевања стварности. Лингвокултурологија настоји описати релацију језик-култура и објаснити постојање културних елемената у језику, односно објаснити начин на који се култура и различити културни модели преламају кроз језик. Према В. Масловој, предмет лингвокултурологије јесу језичке јединице које су попримиле симболичко и метафоричко значење у култури и које уопштавају архетипско и прототипско поимање, сачувано у митовима, легендама, обредима, фолклорном и религиозном дискурсу, поетским и прозним књижевним текстовима, фразеологизмима, метафорама, симболима, пословицама итд. Она је усмерена на изучавање лексичких и концептуалних празнина у језику, језичких јединица које чувају трагове обреда, обичаја, веровања, паремиолошког и фразеолошког фонда језика, митологема и архетипова, еталона, стереотипа, симбола, метафора итд. (Маслова 2007: 35-47).

В. Телија издваја пет канала кроз које култура улази у језик: културне семе, културни концепти, културне конотације, културна позадина и дискурсни стереотипи. Културна сема је део лексичког значења и одражава опште знање о реалији, која најчешће припада материјалној култури. У енциклопедијским речницима ови називи објашњени су одговарајућим етимолошким и културолошким коментарима. Културни концепти су апстрактни појмови

који граде слику света на културно сепцифичан начин. Културна конотација је интерпретативна веза између лингвистичког знака и симбола било ког другог нејезичког кода (стереотипи, прототипи, митови и други ентитети именовани културним обрасцима). Културна позадина је спона између семантике и идеолошког оквира, повезана са историјском ситуацијом, политичким покретом итд. Културни подаци садржани у језичкој јединици могу бити извучени из текста у којем је концепт прво био описан (Телија и др. 2005: 55-75).

3.2. Због својих особености фразеологија представља језгро лингвокултуролошких истраживања. Према речима В. Телије, фразеологизми настају на основу сликовне представе стварности, која одражава свакидашње емпиријско, историјско или духовно искуство језичког колектива, које је безусловно повезано с његовом културном традицијом будући да је субјекат номинације и говорне делатности увек субјекат националне културе (Телија 1996: 
214). За лингвокултуролошки приступ фразеологији важан је појам културне конотације, која подразумева интерпретацију слике у категоријама културе. Могућност да се фразеологизам као језичка јединица тумачи помоћу културног кода, који укључује концепте, стереотипе, еталоне, симболе, митологеме итд. даје овим јединицама културно-националну специфичност.

3.3. Како се у литератури лингвокултурологија сматра и делом - етнолингвистике (в. нпр. Телија 1996: 217), у овом раду се под лингвокултуролошким приступом подразумева и етнолингвистичка метода, која има наглашену дијахронијску и компаративну перспективу посматрања и тумачења грађе. Описани приступ фразеологији у србистици примењују Дргана Мршевић Радовић (2008) и Наташа Вуловић (2015).

Лингвокултуролошка истраживања Д. Мршевић Радовић, обједињена у монографији Фразеологија и национална култура, усмерена су ка реконструкцији фразеолошке слике света, тј. ка описивању елемената српске националне културе наталожених у фразеолошком систему српског језика. Полазећи од акутелног фразеолошког значења, ауторка настоји да утврди унутрашњу форму ових јединица као смисаони садржај базне синтагме у односу на актуелно значење. Детаљном лингвокултуролошком интерпретацијом фразеолошког значења Д. Мршевић Радовић открива најразличитије слојеве традиционалне материјалне и нематеријалне културе уткане у језик, као што су митови о постанку света, древна веровања у демоне и различита митолошка бића и сл. Она показује учешће духовне културе Срба у концептуализацији простора и времена у датој језичкој заједници, што се очитује у прототпиској структури испитаних фразеологизама.

Феноменом културе као мотивационом подлогом фразеологизама бави се и Наташа Вуловић на примерима с религијском компонентом у лексичком саставу, која се реализује као назив црквеног или народног празника, име свеца или религијског бића, антропоним или топоним библијског порекла, назив титуле у црквеној хијерархији, лексема која именује обреде, ритуале, црквену и обичајну праксу, као и радње у вези с њима, име предмета с религијском или црквеном функцијом, као и назив других религијских и црквених појмова. Детаљном лингвокултуролошком анализом, која узима у обзир структурна, семантичка и друга обележја фразеологизама, ауторка показује механизме укључивања културне информације у њихов семантички садржај. Фразеолошка грађа одражава испреплетаност хришћанских елемената с елементима старе српске религије, која се нарочито одражава у аксиолошким опозицијама леп : ружан, добар : зао (пакостан), светло : тамно, истина : лаж, рај : пакао итд.

3.4. Лингвокултуролошким описом фразеологије могуће је успоставити систем еталона, стереотипа, симбола, митологема и других знакова, претворених у вербални код због своје релевантности, који су својствени одређеној говорној заједници као носиоцу одговарајуће националне културе. Тако се у домену психичке и телесне квалификације човека која се остварује фразеолошким средствима може уочити неколико врста еталона. Зец је мера људске плашљивости и брзине (имати зечје сриее, бити плашљив као зец, брз као 
зеи), а бик снаге и здравља (јак као бик), док су мршавост и сувоћа најчешће поистовећени са изгледом предмета (мршав као даска, сув као вретено). Фразеолошка грађа, такође, потврђује и читав низ стереотипа о појединим биљкама и животињама, које често не морају имати реалну основу. Тако се лисици приписује зла лукавост (лукав као лисица, стари лисаи) док се змија одликује мудрошћу (мудар као змија). Симболика боје посебно је изражена кроз контраст светло : тамно, ружичасто : ирно (гледати кроз ирне наочаре : гледати кроз ружичасте наочаре). Затим, по библијском предању, срце је симбол унутрашњег човека, седиште је емоција, интелигенције и мудрости. У њему је, међутим, смештено и начело зла тако да увек постоји опасност од тога да човек крене за својим злим срцем. Ову опозитну симболику одражавају фразеолошки изрази бити чиста срияа : човек зла срияа.

\section{4. Прагматички приступ}

4.1. За разлику од когнитивнолингвистичког и лингвокултуролошког приступа, који су погодни за опис фразеологизама као јединица у систему, прагматички приступ нуди повољне могућности у погледу њиховог описа у контексту, у конкретној комуникативној ситуацији. Док су когнитивна лингвистика и лингвокултурологија углавном усмерене на фразеолошку семантику, прагматика се бави њиховом употребном вредношћу односно мотивима који подстичу употребу одређене фразеолошке јединице у току комуникационог догађаја. Као суштинско може се поставити питање: зашто се у току говорне делатности, када му је на располагању читав низ различитих лексичких јединица, говорник опредељује за фразеолошку. Разлог оваквог поступка јесте њена експресивност као последица обавезног присуства конотативне макрокомпоненте у семантичком садржају фразеологизма. Избор одређеног фразеологизма и његова употреба у контексту регулисани су комуникативном намером говорника, пре свега жељом да оцењујући предмет говора и откривајући емоционални однос према њему, произведе одговарајући учинак код саговорника.

4.2. Захваљујући експресивности, фразеологизми функционишу као прагмеме (Мокијенко 1989: 210), а њихову илокуциону и перлокуциону моћ могуће је пратити како у писаном дискурсу тако и у говору. Иако појам експресивности може бити објашњен на различите начине, ${ }^{4}$ у овом истраживању прихвата се идеја В. Телије, по којој се експресивност разуме као ефекат који се ствара код саговорника у току говорног процеса изражавањем емотивног става говорника према означеном (Телија 1986: 7). ${ }^{5}$ Ако говорник намерава да на одређени начин делује на саговорника, своју говорну стратегију организоваће на посебан начин, пре свега, одабирајући она језичка средства која

\footnotetext{
${ }^{4} \mathrm{O}$ томе в. нпр.: Тошовић 2004.

${ }^{5}$ Према А. Пејановић, компоненте експресивности су емоционалност, сликовитост, интензивност и субјективна оцена (вредносни став) (Пејановић 2016: 361-367).
} 
су носиоци става и оцене, садржане у конотативној макрокомпоненти њиховог значења. При томе се под конотацијом подразумева семантичка макрокомпонента која одражава емотивно-вредносни и стилистички маркиран однос говорника према стварности при њеном обележавању у исказу, који на основу те информације производи експресиван ефекат (Телија 1986: 16). Ова компонента значења је, дакле, дводелна и састоји се од оцене (тј. вредносног суда) говорника и његовог емотивног односа према неком објекту из света стварности о којем се реферише. Стога се експресивним језичким јединицама обавља двострука функција: квалификација неког појма и интерпретација те квалификације (Телија 1986). У фразеолошкој семантици доминантан је управо субјективан аспект који проистиче из описане конотације. Оцена одређеног појма заснована је на систему вредности успостављеном у датој лингвокултурној заједници, а као њен когнитивни оператор функционише глагол сматрати (Телија 1996: 186-187). Њу допуњује емотивна компонента која одражава емоционални однос у виду презира, потцењивања, осуде, неодобравања и сл., а она је на известан начин регулисана нормом (Телија 1996: 202-213). Она произилази из унутрашње форме фразеологизма засноване на асоцијатвно-сликовном повезивању садржаја, најчешће метафоричном. Сликовна гешталт структура која је у основи фразеологизма може се описати помоћу оператора замислити и представити себи (Телија 1996: 187-202). ${ }^{6}$

4.4. Успешна комуникација међу учесницима подразумева правилно тумачење поруке која се емитује од пошиљаоца ка примаоцу. Уколико се говорник одлучи да поруку вербализује употребом фразеологизма као експресивне језичке јединице, процес њеног разумевања постаје знатно сложенији. Наиме, прималац тада мора располагати не само знањем о значењу фразеологизма, његовој денотацији, већ и о ситуативном оквиру у који се исказ смешта, затим о његовој конотативној вредности, као и културно-националним специфичностима уколико су оне асоциране мотивационом основом. Тако се фразеологизам камен спотицањ $a^{7}$ у наслову новинског текста може правилно разумети ако се има у виду цео текст, као и нејезички контекст, који између осталог укључује и ситуацију из света стварности о којој се реферише. Иако израз носи своје самостално значење (што је потврђено у речнику дефиницијом 'узрок, повод свађе, раздора'), о његовој референцијалној вредности сазнаје се тек његовим укључивањем у шири оквир. Предметни део значења израза обухвата односе између Србије и Русије, који због блискости представљају проблем у односима између Србије и Европске уније, што је недвосмислено сугерисано поднасловом: Србија је добила нову пацку због

\footnotetext{
${ }^{6}$ Веома добар модел у изучавању семантике експресивне лексике нуди С. Ристић која се и сама ослања на теоријске поставке В. Телије $(1986,1996)$. Имајући у виду сложеност семантичке реализације експресивних лексема у дискурсу, ауторка успоставља следећи вид компонентне структуре именичких експресива с општим значењем: 'особа + морална или психичка особина': денотативна компонента, компонента објективне оцене, компонента субјективне оцене, емотивна компонента, експресивна компонента стилског типа, експресивна компонента прагматичког типа и функционално-стилска компонента (Ристић 2004: 63-64).

${ }^{7}$ Пример је преузет са сајта дневног листа Блиц (https://www.blic.rs/vesti/politika/kamenspoticanja-srbija-je-dobila-novu-packu-zbog-odnosa-sa-rusijom-a-ova-lista/4g82f7t).
} 
односа са Русијом, а ова листа открива ита смо све одбили због Москве. Конотативност фразеологизма иде у правцу негативног, ка неповољној оцени и неодобравању аутора текста, што открива не само његов субјективан однос према предмету о којем је реч, већ вероватно и став целог уредничког тима. Тако фразеологизам служи као средство двоструке квалификације: њиме се приписује одређена квалификација неком појму, која пролази кроз субјективну интерпретацију, тј. оцену говорника. Овако оформљена порука треба да изазове одређени учинак код читаоца када је он декодира.

\section{5. Закључак}

Имајући у виду предности понуђених теоријско-методолошких приступа, закључујемо да се права природа фразеолошких јединица може одгонетнути уколико се описани модели комбинују. Когнитивнолингвистички и лингвокултуролошки приступ обезбеђују адекватну методологију у разумевању њихове семантике и уопште у сагледавању фразеологизма као јединице језичког система. Прагматички приступ, који узима у обзир и ванјезичке околности комуникације, у првом реду оне које се непосредно тичу њених учесника - намере адресанта и учинка оствареног код адресата, затим саме говорне ситуације, претходног знања и сл., допуњује поменуте теоријско-методолошке оквире и омогућава прецизнију интерпретацију.

\section{ЛИТЕРАТУРА}

Апресјан 1995: Ю. Д. Апресян, Интегральное описание языка и системная лексикография. Изабраные труды II, Москва: Школа „Языки русской культуры".

Бартмињски 2011: Ј. Бартмињски, Језик-слика-свет. Етнолингвистичке студије, Београд: SlovoSlavia.

Добровољски/Пирјанен 2005: D. Dobrovol'skij, E. Piirainen, Cognitive Theory of Metaphor and Idiom Analysis, Jezikoslovije, 6/1, 7-35.

Кевечеш 2010: Z. Kövecses, Metaphor. A Practical Introduction (second edition), Oxford: Oxford University Press.

Лејкоф/Џонсон 2003: G. Lakoff and M. Johnson, Metaphors We Live By, Chicago - London: The University of Chicago Press

Маслова 2007: В. А. Маслова, Лингвокультурология. Учебное пособие, Москва: Издательский центр „Академия”.

Матешић, 1982: J. Matešić Frazeološki rječnik hrvatskoga ili srpskog jezika, Zagreb: Školska knjiga.

Мокијенко 1989: В. М. Мокиенко, Славянская фразеология, Москва: Высшая школа. 
Мршевић Радовић 2008: Д. Мршевић-Радовић, Фразеологија и нащионална култура, Београд: Друштво за српски језик и књижевност Србије.

Пејановић 2016: А. Пејановић, Експресивност као категоријална особина фразеолошких јединица, Научни састанак слависта у Вукове дане, 45/1, 361-367.

Попова, Стерњин 2007: 3. Д. Попова, И. А. Стернин, Когнитивная лингвистика, Москва: Восток-Запад.

Ристић 2004: С. Ристић, Експресивна лексика у српском језику: теоријске основе и нормативно-културолошки аспекти, Београд: Институт за српски језик САНУ.

РМС - Речник српскохрватскога књижевног језика, I-III, Нови Сад - Загреб: Матица српска - Матица хрватска, 1967-1969; IV-VI, Нови Сад: Матица српска, 1971-1976.

РСАНУ - Речник српскохрватског књижевног и народног језика, Београд: Институт за српски језик, САНУ, 1959-.

Телија 1986: В. Н. Телия, Коннотативный аспект семантики номинативных единиц, Москва: Наука.

Телија 1996: В. Н. Телия, Русская фразеология. Семантический, прагматический и лингвокультурологический аспекты, Москва: Школа „Языки русской культуры".

Телија и др. 2005: V. Teliya, N. Bragina, E. Oparina, I. Sandomirskaya, Phraseology as a Language of Culture: Its Role in the Representation of a Collective Mentality, in: A. P. Cowie (ed.), Phraseology. Theory, Analysis, and Applications, Oxford: Oxford University Press, 55-75.

Тошовић 2004: B. Tošović, Ekspresivnost, Stil, 3, 25-61.

Џонсон 1987: M. Johnson, The Body in the Mind. The Bodily Basis of Meaning, Imagination, and Reason, Chicago and London: The University of Chicago Press.

Џонсон 2007: M. Johnson, The Meaning of the Body: Aesthetics of Human Understanding, Chicago and London: The University of Chicago Press.

Шипка 2006: D. Šipka, Osnovi leksikologije i srodnih disciplina, Novi Sad: Matica srpska.

Gordana R. Štrbac

\section{PHRASEOLOGICAL UNIT AND THEORETICAL APPROACHES IN ITS STUDY}

Summary

Phraseologisms are linguistic units of specific grammatical and semantic features, characterised by reproducibility, idiomaticity, and syntactic and semantic non-compositionality. So they must be approached from several different angles. First, given that they are not only a linguistic fact, but can be also considered as a product of our conceptual system, which is created via cognitive mechanisms, primarily metaphor and metonymy, they are seen from the point of view of cognitive semantics. Second, they convey the cultural information, they are also considered from the aspect of linguoculturology. 
And finally, a proper understanding of phraseology requires taking into account all of the communicative situation so that these units are also considered from the angle of pragmatics. In this paper, the combination of the approaches is proposed.

Key words: phraseologism, cognitive linguistics, linguoculturology, pragmatics. 